\title{
The Use of Cohesive Devices in the Writing of Senior High School Students in Kebumen
}

\author{
Atik Muhimatun Asroriyah \\ Yogyakarta State University \\ Yogyakarta, Indonesia \\ atik.muhimatun2016@studentuny.ac.id
}

\author{
Bambang Sugeng \\ Yogyakarta State University \\ Yogyakarta, Indonesia
}

\begin{abstract}
This study analyzed the use of cohesive devices in the students' writing in senior high school students at tenth grade in academic year 2017/2018. The sample of this research were three groups of students in three of school that divided into three areas which are urban, sub-urb, and rural area. There were 96 students composition to be analyzed in this study. The data were collected by students' composition in making report text thas was analyzed by using the theory of cohesion by Halliday ad Hasan (1976), this research intended to investigate the cohesive devices used by the students, the cohesive devices used prominently, and the differences of the use of cohesive from each school. A qualitative research methodology was used to analyze the writing of the three groups to reveal the points of strengths and weaknesses in their writing. The analyzed was concerned with: grammatical cohesion (reference, substitution, ellipsis, conjunction) and lexical cohesion (reiteration and collocation). The result show that there was a difference occurrence of cohesive devices from each school. This study reveal that three groups of the students produced four the major of cohesive devices. There were reference, subtitution, conjunction, and lexical cohesion. The data from three of school explained that the sub-urban school most dominantly used cohesive devices; lexical cohesion is the highest occurrence in this group then followed by conjunction, ellipsis, and subtitution the lowest occurence.
\end{abstract}

Keywords-cohesive devices; cohesion; writing; report text; grammatical cohesion; lexical cohesion

\section{INTRODUCTION}

Writing is a productive skill which students produce sentences to convey a message in the written text [1]. Writing is also a complex activity which requires the writer delivering their ideas, thoughts, and opinions to the reader to share information. That statement is also supported by [3] that writing is an important skill in the teaching learning process. The skill of writing will help much if one wants to contact other people through mass media. Through writing, one can communicate and share information with others.

Based on my preliminary study with some teachers in the Senior High School in Kebumen, mastering writing skills becomes the basic problem. Students still use the first language pattern in write a text, so the first language influence the target language. Besides, they face problems in generating and organizing ideas. Teachers at schools may focus on the sentence level more than the discourse level and thus they do not emphasize such cohesive devices. Cohesion and coherence are considered as the two important features of good writing. So much attention should be paid to generating and organizing ideas in general and to the role of cohesive devices particularly. The main focus of teaching writing is to develop competency in creating a good writing. To achieve a good writing, the text should be coherent and cohesion [1].

[5] state that cohesion is semantic relation between one element and another element in the text. Cohesion occurs when the sentences of the element interpret another item that connecting each other. Moreover, Cohesion is one of the main characteristics that should be considered in producing a good writing [6]

Since the use of cohesive devices is important, the writer conduct research upon the use of cohesive devices in learner's writing, in this case in the form of report text. The paper aims to find out the use of cohesive devices in the students' writing, to find out the use of cohesive devices prominently used by the student's writing, find out the differences in the use cohesive devices of each school and find out the differences in the use cohesive devices of each school.. In order, to obtain the answer, some underlying theories will be discussed, such as the definition of cohesive devices and the type of cohesive devices.

\section{LITERATURE REVIEW}

\section{A. Text}

A text is an object which can be read or heard in the form of written or spoken language. [5] argued that a text refers to any passage that can be spoken or written, it is more than one sentence in a paragraph, and they have meaning that connect each other.

Meanwhile, [7] stated that a text is an object which can be analyzed and described by the reader or writer in a particular context. It means that a text can be oral and written. A written text is a text that is produced by a writer; bearing in mind the grammatical structures, discourse connections like cohesive devices that are used in the text, and the meaning of the text. Meanwhile, a spoken text is utterance that is produced by a speaker, for example; speech and oral conversation. Sometimes, the speaker does not take notice of the grammatical structure because an oral text depends on the speaker's utterance. 


\section{B. Cohesion}

Cohesion is a semantic relation between elements in the text. The concept of cohesion is a semantic unit; it refers to relations of meaning that exist within the texts [5] It means that cohesion occurs when the sentence of the elements interpret to another item that connect each other.

[8] defined that cohesion refers to the connections that have their manifestation in the discourse itself. It means that cohesion related with discourse the following by the devices of cohesion. Moreover, [9] added that cohesion as the network of lexical grammatical and other relations which provide links between kinds of part of the text. He also said that there are devices which contribute to provide link among parts, it is usually call as cohesive devices. Cohesion is achieved through cohesive device such as reference, ellipsis, substitution, conjunction, and lexical cohesion [5].

Reference is the specific nature of the information that is signaled for retrieval. In the case of reference, the information to be retrieved is the referential meaning, the identity of the particular thing or class of things that is being referred [5] The term reference divided into three part; Personal reference (he, they, him, etc.), demonstratives (this, these, that, those, here, there, etc.), and comparative reference (another, same, similar, such, so, etc.).

Substitution is the replacement of one item by another. It is a relation between linguistic items, such as words or phrases, rather than a relation between meanings and this distinguishes it from reference. The difference between substitution and reference is that substitution lies in the relation between words, whereas reference between meanings. There are three types of substitution: nominal, verbal, and clausal. Nominal substitution is substituting a noun or a nominal group with another noun. Elements of this type are one, ones, and same. Conjunction signals a relationship between parts of the discourse by linking them. Conjunctions can be further classified into four categories: additive (and, furthermore, additionally, too, etc.), adversative (but, rather, yet, on the other hand, etc.), causal (therefore, so, as a result, for this reason, etc.), and temporal (then, next, first, in conclusion, etc.). [10]

Lexical cohesion, according to Halliday and Hasan [5, p. 274], lexical cohesion is the cohesive that is established through the structure of the lexis or vocabulary. There are two types of lexical cohesion, reiteration and collocation. Reiteration are divided into four categories; repetition, synonym, superordinate, general word.

\section{ReseARCh MEthodology}

\section{A. Participants}

The participant of this research are three class from three school of Senior High School in Kebumen at tenth grade students. These school are devided into three categories, first SMA N 1 Kebumen as urban school (group 1), second SMA N 2 Kebumen as the sub-urban school (group 2), and the last SMA N 1 Kutowinangun as rural school ( group 3).

\section{B. Instrument}

The instrument of this research was the researcher itself, the students composition and the table analysis. Moleong states that in the qualitative research, the researcher plays the roles as the designer, data collector, analyst, data interpreter, and eventually the reporter of the research findings. Besides, data from the students writing and table of analysis or rubric served as secondary. The second instruments have been validated by some experts. The validation through the following steps, the first the researcher make a draft of the instrument, second, search some expert that relevant to the topic of the research, then the experts validated the instrument, and the last the researcher revise the instrument if there is comment.

\section{Data Analysis}

The instrument of this research was the researcher itself, the students' composition and the table analysis. Moleong states that in the qualitative research, the researcher plays the roles as the designer, data collector, analyst, data interpreter, and eventually the reporter of the research findings. Besides, data from the students writing and table of analysis or rubric served as secondary. The second instruments have been validated by some experts. The validation through the following steps, the first the researcher make a draft of the instrument, second, search some expert that relevant to the topic of the research, then the experts validated the instrument, and the last the researcher revise the instrument if there is comment.

\section{RESUlt AND DisCUSSION}

\section{A. Result}

TABLE I. TYPE OF COHESIVE DEVICES

\begin{tabular}{|c|c|c|c|c|}
\hline Type & Group 1 & Group 2 & Group 3 & Total \\
\hline Reference & 799(33.4\%) & 869(36.3\%) & $722(30.2)$ & 2390 \\
\hline Ellipsis & 0 & 0 & 0 & 0 \\
\hline $\begin{array}{l}\text { Subtitutio } \\
\text { n }\end{array}$ & $3(75 \%)$ & $1(25 \%)$ & 0 & 4 \\
\hline $\begin{array}{l}\text { Conjuncti } \\
\text { on }\end{array}$ & $\begin{array}{l}362 \\
(32.4 \%)\end{array}$ & 408 (36.52\%) & $347(31.06)$ & 1117 \\
\hline $\begin{array}{l}\text { Lexical } \\
\text { Cohesion }\end{array}$ & $\begin{array}{l}\text { 1312(40.3 } \\
\%)\end{array}$ & $\begin{array}{l}1046(32.18 \% \\
)\end{array}$ & 892(27.4\%) & 3250 \\
\hline Total & 2476 & 2324 & 1961 & 6761 \\
\hline
\end{tabular}

This table shows the type of cohesive devices in the students writing. The frequency of cohesive relations in student's writing were 6761 representing the total number of cohesive devices that are used by the three group of school in the three area. The number of reference used by the students in group 1 was approximately 33.4\%, where there were about 799 words been appear in those 2390 words contained in the entire essay writing in report text, While in the group two were 869 equal to $36 . .3 \%$ and group three were 722 occurance equal to $30.3 \%$. Reference from group two was highest than other group, while from another devices reference was higher. Another type of cohesion was subtitution that was lowest than 
other devices, the frequency from group 1 were 3 equal to $75 \%$, then from group 2 were 1 equal to $25 \%$ and group three there is no subtitution occurance in the students writing. Conjunction occurance in the group 1 were 362 equal to $32.4 \%$, group 2 were 408 occurance equal to $36.52 \%$, and group 3 were 347 occurance equal to $31.06 \%$. Total number of conjunction occurance was 1117 times. And the last cohesion devices was lexical cohesion, for group 1 lexical cohesion were 1312 times equal to $40.3 \%$, group 2 were 1046 times equal to $32.18 \%$, and the last group 3 were 892 times equal to $27.4 \%$. Total number of occurance were 3250 times. Lexical cohesion was the highest or dominant used in the students writing and followed by reference, and the lowest occurance was subtitution.

\section{B. Discussion}

The result of this study shows that there are four cohesion devices appeared in the students, they are reference, subtituion, conjunction and lexical cohesion.

\section{1) Reference}

References is the information of signal and retrieval. The identity of the writer or the part of the text that is being told has referential in the meaning, we can see it before or after the word that becomes reference. There are three of reference. Personal reference, demonstrative reference, and comparative reference. The use of reference was found in the students writing, the extract below serves as an example on how reference was used in

the essays of the students.

\section{Extraxt 1}

" they are called wild animals. They keep their eggs well. The eggs around the lake or river move precisely in the land area"

The underline word before are the personal reference. Personal reference relates with the speech situation through categorie of person. Another of personal reference that was found in the students writing were " $i$, you, they, we,them, its, one" . For the personal reference, the occurance in the text were same of each text.

The word that underline red was example of demonstrative reference, another demostrative reference that was found were " this, there, those, the, that" but the dominant used was determiner "The".

Comparative reference is indirect reference by means of identity or similarity. The reasearcher found comaparative reference in the students writing. See the extraxt 2 below.

"most crocodiles live in freshwaer rivers, but some live in water with PH less than sevent or in saltwater".

Another comparative referebce also found, they were “ more than, same, as, better". The dominantly used was the word more than and as.

\section{2) Subtitution}

Substitution is the replacement of one item by another. It is a relation between linguistic items, such as words or phrases, rather than a relation between meanings and this distinguishes it from reference. The extract 3 below were the example of subtitution. "female crocodile keep the egg by burried under body or sand mixed with the leaves. The male crocodile also $\underline{\text { do }}$ it together keep the egg."

Demonstrative reference here was the lowest occurence in the students writing. it because the students didn't understand about the material subtitution.

\section{3) Conjunction}

Conjunction is the relationship which indicates how the subsequent sentence or clause should be linked to the preceding or the following (parts of the) sentence. This is usually achieved by the use of conjunctions (also known as connectives). Below the extraxt 4 below the example of conjunction in the students conjunction.

" The crocodile including the cold-blooded animal, so it often expose its body and opened its mouth."

"beside living in the river, crocodile also commonly seen in the lake"

"most crocodiles live in freshwaer rivers, but some live in water with PH less than sevent or in saltwater".

The underline word before were the example of subtituion. Subtituion is divided into four categories, such as additive, adversative, causal, and temporal. The example of additive were "and, also, or, beside". While the word " but" the example of adversative conjunction. The word " so" belongs to causal conjunction. Temporal conjunction was rarely used in the students writing, but there were an example " next, after that, and soon."

\section{4) Lexical Cohesion}

Lexical cohesion is the cohesive that is established through the structure of the lexis or vocabulary. There are two types of lexical cohesion, reiteration and collocation. Reiteration is a form which including the repetition, synonym, antonym, superordinate, and general word of lexical item. Collocation is a form of lexical cohesion achieved through the association of lexical items that regularly co-occur.

The extract 5 below are the example of lexical cohesion.

" crocodile is a reptile. Crocodile live in land and river."

“ a sturdy jaws to pounce on its prey and strong teeth. with sharp teeth it eats the prey with ease”

" the crocodile including the cold-blooded animal"

“ crocodile belongs to ovipar animal because it produce eggs”

The underline word " crocodile, prey" then repeat again write "crocodile, prey" it can be called repetition. Then, the underline word " cold-blooded animal " belong to colloction. And the last “ ovipar , reptile, and eggs' belongs to superordinate because it can be separated into sereval categories. 


\section{CONCLUSION}

According to the discussion of results presented before, there is a difference in the three if school of the students' writing use of cohesive devices in frequency, variety, and control.

Cohesive devices are important features of academic writing which connect the sentences together in a text and make it cohesive. The main purpose of cohesive devices is to help readers make logical connections between sentences. Writers use these devices in their academic writing in order to make their writing more accurate and comprehensible. The results of this study showed that the researchers found the rural school lower of the use cohesive devices than other school, it may be the teacher didnt teach about the material that related with the cohesion and the teacher didin't add learning media to added the knowledge and interesting students in English. Because, some problem that researcher found many students did not like English. The problem can be solve by improve their reading ability and can help them to know what kind of discourse they have to produce and understand in academic settings.

The highest occurrence found in the sub urban school. It because the teacher teach the material about cohesion and the knowledge or the bank of vocabulary's students are rich. Meanwhile, the urban school the occurrence of cohesive devices be in between those school.

It can be said that the place of school determine the achievement of the students. It is recommended that this discovery on the weaknesses of the future language educators must be addressed as early as possible to better equip them with the necessary knowledge and skills to be effective in their area of specialization. Additional academic writing instructions can be taken to help enhance the writing quality of these learners. Curriculum planners and university administrators also need to evaluate whether the subjects for English teaching majors are still relevant and responsive to the needs of the learners to prepare them in the world of English language teaching.

\section{REFERENCES}

[1] Marjohan, Andayani, and Seken, "An analysis of the cohesion and coherence of the students narrative Writings," English Language Education Program Post Graduate Program. Ganesha University of Education, Singaraja, Indonesia, 2014, p. 1. [Online]. Available: pasca.undiksha.ac.id.

[2] K. Venkanna, "Do ESL Learners Use Conjunctions As 'Cohesive Devices’ In Writing?” A Study. Int. J. of Engl. Lang., Lit. and Human. (IJELLH), 2015.

[3] J. Harmer, How to Teach Writing. New York: Longman, 2004.

[4] W. Saud, "Cohesion in the Descriptive Writing of EFL Undergraduates,” Int. J. of Human. and Cult. Stud. (IJHCS), vol. 2, no. 2, 2015. ISSN 2356-5926.

[5] M. A. K. Halliday and R. Hasan, Cohesion in English. London, England: Longman, 1976.

[6] M. Hadi, "The comparison of cohesive devices in English and Indonesian descriptive text," Thesis, English Language Education Graduate Program, Semarang State Univ., 2016.

[7] K. Hyland, Second Language Writing. Cambridge: Cambridge University Press, 2003, p. 6.

[8] J. Renkema, Discourse Studies: An Introductory Textbook. Amsterdam: John Benjamins Publishing Company, 2004, p. 103.

[9] M. Baker, In Other Words: A Course Book on Transition. Beijing: Foreign Language Teaching and Research Press, 2000.

[10] H. Adiantika, “Cohesive devices in EFL students' expository writing," vol. 4, no. 1, December 2015. ISSN 2301-7554. 